\title{
Observations on the Anatomy of the Leaf in the Osmundaceae.
}

\author{
BY \\ D. T. GWYNNE.VAUGHAN.
}

With Plate XIII

$\mathrm{T} \mathrm{N}$ a paper published in $1908^{1}$ by Dr. R. Kidston and the author; on the origin of the adaxially curved leaf-trace of the Filicales, it was suggested that the changes in form exhibited by the leaf-trace of the Osmundaceous fossil Thamnopteris Schlechtendahlii ${ }^{2}$ as it passes through the cortex of the stem indicated the actual manner of the evolution of the typical filicinean $\mathrm{C}$-shaped trace. According to this view it is assumed that all the various forms of the leaf-trace in the Filicales may be traced back to a single ancestral type already possessing a dorsiventral symmetry. This primitive leaf-trace contained a solid central mass of xylem, more or less elliptic in transverse section, the short axis of the ellipse corresponding to the median plane of symmetry of the leaf. The protoxylems were immersed (mesarch), and, at a still earlier stage, it may be assumed that they were derived from a single median strand. Phloem probably occurred on both sides of the xylem.

From this simple leaf-trace it is possible to derive all the various forms found in the Zygopterid petioles and also the adaxially curved, C-shaped leaf-trace in all its protean disguises. The Zygopterid line of evolution starts by the substitution of parenchyma for the lateral tracheae on the outside of the two protoxylems, so as to give rise to two lateral islands or bays. ${ }^{3} \quad$ The $\mathrm{C}$-shaped line of descent is initiated by replacing the tracheae on the adaxial side of the protoxylems by parenchyma, so as to give rise to a single adaxial island or bay.

[Figures illustrating this hypothesis are given in the paper on the Origin of the Adaxially Curved Leaf-trace ${ }^{1}$ and in the Fossil Osmundaceae, Part IV. $\left.{ }^{3}\right]$

1 Gwynne-Vaughan and Kidston: On the Origin of the Adaxially Curved Leaf-trace in the Filicineae. Proc. Koy. Soc. Edin., vol. xxviii, Part vi, 1908, p. 433.

2 Kidston and Gwynne-Vaughan: On the Fossil Osmundaceae, Part III. Trans. Roy. Soc. Edin., vol. xlvi, Part iii, 1909, p. 65 I, Pl. IV.

${ }^{3}$ Kidston and Gwynne-Vaughan: On the Fossil Osmundaceae, Part IV. Trans. Roy. Soc. Edin., vol. xlvii, Part iii, 1910, p. 469.

[Annals of Botany, Vol. XXX. No. CXX. October, 1916.] 
The ancestral fern leaf is regarded as having a single row of branches on each side of the rachis. It follows, therefore, that the double row of branches on each side of the petiole possessed by some Zygopterideae is held to be a special development evolved within this affinity and one probably related to the assumption of an erect habit of growth by the leaf and the consequent arrangement of the lateral appendages in a more or less radial manner to avoid overshadowing.

We may now consider the way in which the lateral branches of this primitive leaf may be assumed to have received their vascular supply from the rachis. It seems probable that, when about to give rise to a branchtrace, one of the lateral protoxylems would elongate in the direction of the long axis of the ellipse and then divide. A small mass of xylem would then protrude from the lateral margin of the trace, enclosing the outer protoxylem, and this would eventually be constricted off as the branch-trace. In the Zygopterid affinity this conjecture receives a considerable amount of support, because in the petiole of Asterochlaena, ${ }^{1}$ which is on all grounds still fairly close to the common ancestor, a process very near to this is known to take place, the only complication being that the lateral islands of parenchyma are already present.

It was to see whether the C-shaped leaf-trace still retained any features which might indicate the primitive method of branching that the following investigation was made.

The manner in which the vascular supply of a branch is given off from its mother-axis in the Osmundaceous leaf varies in the same petiole according to the order and position of the branch in question. The simplest methods are to be found where the smaller veins depart from the midrib of the lamina or where small secondary pinnae arise on the rachis of a primary branch. In these cases the xylem strand of the trace is too small and thin to exhibit the features of special interest present in the branching of the stouter but still quite small traces to which our attention will be mainly directed. In the very simple branchings referred to above, the xylem strand of the trace may be reduced to an almost straight transverse band, as in Osmunda Claytoniana (Pl. XIII, Photo I), or it may still form a wellcurved crescent, as in Todea barbara. In either case the endarch protoxylem on the side of the branching divides into two (Photo I) and the xylem strand constricts between the two protoxylems so as to nip off the outer of them for the trace of the branch (Photo 2).

In somewhat larger though still quite small branchings, when the outline of the trace varies from elliptic to more or less reniform in transverse section and the xylem strand is a fairly stout and well-curved $C$ with two to four groups of protoxylem, the procedure is most often as follows. As the

1 Paul Bertrand: Structure des stipes d'Asterochlaena laxa, Stenzel. Mém. de la Société Géologique du Nord, t. vii, p. I. Lille, 1911. 
point of branching is approached from below, the end of the xylem strand of the trace on the side of the branch becomes somewhat thickened. The protoxylem strand on that side also elongates laterally and prolongs itself into the thickened extremity of the xylem strand so that it becomes immersed. There is now a certain amount of the metaxylem of the thickened end of the strand on the adaxial side of the protoxylem; this adaxial xylem may be regarded as centripetal (Photos 3 and 5). The elongated protoxylem now divides into an inner and an outer lateral protoxylem, the two becoming separated by a few elements of metaxylem (Photos 3 and 6). The inner protoxylem is still endarch, touching on the concave margin of the xylen strand, but the outer is mesarch, being completely immersed in the metaxylem of the thickened and laterally prolonged end of the same. The outer protoxylem, together with the metaxylem lying to the outside of it laterally, is now nipped off by the incursion of a groove or furrow of parenchyma beginning on the adaxial side and gradually passing through the thickened end of the xylem strand of the parent trace to the abaxial side (Photos 4 and 7).

Sometimes this groove of parenchyma begins so soon that it reaches the immersed protoxylems before they have become separated from each other by metaxylem. The inner protoxylem is in this case for a while in contact with parenchyma both on the inside and the outside, and there is an isolated mass of centripetal metaxylem on its adaxial side (Photos 8 and 9). This soon joins up with the abaxial metaxylem on the outside of the inner protoxylem, which thus becomes normally endarch again.

In some cases of branching the lateral protoxylem of the xylem strand passes completely into the thickened end and becomes definitely mesarch (Photo I0). In these cases it may divide as before, the outer protoxylem passing off with the branch-trace, the inner opening out into the concavity of the parent trace and becoming endarch once more. The inner protoxylem may, however, still remain mesarch for some distance after the departure of the branch-trace before becoming endarch (Photo II).

In some cases the mesarch protoxylem does not divide at all, but passes out as such with the trace. Here, of course, the xylem strand of the mother axis will have one protoxylem less above the branch than it has below (Photos $\mathrm{I}_{2}$ and $\mathrm{I} 3$ ).

In the smaller branchings of this type, when the end of the xylem strand is but slightly thickened, the centripetal elements on the adaxial side of the dividing protoxylem are very few-three, two, or only one (Photo I4). It is obvious that these are transitional stages to the simplest type of branching already described.

Another type of branching, which must be regarded as an advance on the type just described, is usually found in somewhat larger branchings. When the lateral protoxylem of the mother axis is prolonged laterally into 
the thickened end of the xylem strand it is accompanied by the soft tissues that line the concavity of the trace. Sometimes these are represented by a few layers of the xylem sheath lying on the adaxial side of the protoxylem and forming a bay between it and the centripetal metaxylem. In more advanced cases the phloem and pericycle also behave in the same way. Accordingly just below the departure of a trace the xylem strand is more or less strongly bulged outwards on that side (Photos $\mathrm{I}_{5}$ and I7). The protoxylem divides as before, and at about the same time the curve of the xylem breaks across on its adaxial side a short distance from its extremity (Photos 16 and 18 ). The small mass of xylem thus left behind gradually becomes joined on to the rest of the xylem strand, usually a little to the outside of the inner protoxylem, so that the latter continues to be endarch. More rarely the adaxial xylem joins on immediately in front of the inner protoxylem, so that this becomes temporarily mesarch.

This adaxial mass of xylem can only be regarded as representing the centripetal xylem in the previously described method of branching. It is interesting to note that in some cases it also may become very scanty, being reduced to one or two tracheae only (Photo 19), thus furnishing another method of transition to the simplest type of branching first described.

The further development of the method of branching is related in quite a simple manner to the increase in size of the parent trace and of the trace of the branch. As the latter becomes larger the bay becomes wider and its central region becomes invaded by the endodermis and the central ground tissue of the parent trace, so that the departure of the branch-trace leaves a gap in the parent trace communicating directly with the external ground tissue. This is the case in Todea barbara, Todea superba, Osmunda bipinnata, and Osmunda javanica. If the branch-trace is curved into a ring at the point of attachment, as in Osmunda regalis, it opens out a short distance above. In Todea hymenophylloides, Osmunda regalis var. palustris, and Osmnnda regalis var. japonica the parent trace is not interrupted even at its largest branchings.

The position in the leaf at which any particular type of pinna-trace departure is to be found varies greatly from one plant to another and even from leaf to leaf, and seems to depend a good deal upon the stature and vigour of the leaf.

The simplified or reduced type of branching can arise on the one hand by the loss of the centripetal xylem on the adaxial side of a mesarch protoxylem immersed in a solid mass of xylem, or on the other hand by loss of the xylem mass on the adaxial side of a bay of parenchyma. Since the method of branching with a bay of parenchyma is derived from that with a solid thick-ended xylem strand the two methods are connected and the missing adaxial xylem is the same in the two cases. 
In considering the relative primitiveness in the structure of the trace in the different regions of the leaf a great deal of caution must be exercised. It seems clear that the highest complexity in structure is to be expected, and indeed is actually to be found at the base of the free petiole, for this region must negotiate the water-supply for the whole leaf and must also bear the strain of the total weight unassisted by the stent. The leaf-trace in the cortex of the stem is relieved of the duties of mechanical support and is free to retain more primitive characters, In the upper region of the rachis, at any rate above the first lateral branches, and in these branches themselves the duties both of support and of conduction progressively diminish, and here again a simpler construction would at any rate be feasible.

So far as the structure of the trace itself is concerned this certainly holds good in the Osmundaceae. Starting from a point just above its base the petiole may be said to indicate broadly its phylogeny in two directions, both upwards and downwards.

With regard to the manner of branching, however, other factors come into play and the matter is on a different footing. Speaking generally the method of branching becomes more primitive on passing higher up the main rachis and in its lateral branches. Still it must be remembered that in some species the lowest branches of the rachis and of the primary branches are themselves reduced in size, being markedly smaller than some of those higher up. This reduction affects the method of branching so that it may present features of a more or less primitive type.

The apical pinnae of the rachis and its branches are about the same size and have about the same work to perform as the earlier leaves of the young sporeling. In consequence, as we proceed down from the apex of the leaf we may expect to meet very much the same series of changes in the vascular system as we should if we were examining the young leaves of the sporeling passing from leaf to leaf $u p$ the stem. So far as we have been able to follow it this is indeed the case in Osmunda, with one distinction, that the thickening of the xylem at a branching and the immersion of the protoxylem are omitted in the sporeling. It may be that the phylogeny of the earlier leaves is distinct from that of the later leaves and that, owing to the small size of their traces, these features could not appear.

In the largest branchings of Osmunda regalis the median axis of symmetry of the branch-trace is almost at right angles to that of the parent trace. It is rather less inclined in the other species of Osmunda. In all the smaller branchings it becomes still less inclined and may become quite parallel to the axis of symmetry of the parent trace. In Todea the median axis of the branch-trace is actually at right angles to the parent trace in large branchings and is still inclined to it at a wide angle even in the smaller branchings, though it may become almost parallel in Todea hymenophylloides. 
The facts described in this paper have an evident bearing on the regions of the $\mathrm{C}$-shaped trace. If the above interpretation of the phenomena be accepted it is clear that in the xylem strand of the petiolar trace in the neighbourhood of the smaller branchings we have to deal with three distinct regions :

(a) the abaxial curve of the xylem strand;

(b) a lateral portion which is going to pass out into the branch;

(c) a mass of centripetal xylem that is going to remain in the mother trace.

This makes a line drawn across the adaxial points of departure of the branch-traces a very important distinction, ${ }^{1}$ because it divides the parent trace into portions corresponding to the abaxial (centrifugal) and adaxial (centripetal) halves of the presumed ancestral trace. In the larger trace these regions are still present, all enlarged but unequally so. The greatest extension is experienced by the abaxial curve, but the centripetal xylem also increases in volume and may acquire a protoxylem or even two of its own.

\section{DESCRIPTION OF THE FIGURES IN PLATE XIII.}

Illustrating Professor Gwynne-Vaughan's paper on The Anatomy of the Leaf in the Osmundaceae.

(All these figures are from untouched photographs.)

$p x_{0} . i$, inner protoxylem remaining in the parent trace; $p x . o$, outer protoxylem departing with the branch-trace; $p x$., undivided protoxylem; $a d . x y$., the adaxial or centripetal metaxylem.

Photos I and 2. Osmunda Claytoniana. Origin of trace to small secondary pinna. No adaxial xylem present, the branch-trace being simply nipped off. ( $x$ I 40.$)$ Slide No. 1983 .

Photos 3 and 4. Todea superba. Origin of trace to ninth pinna from the base of the leaf. ( $x$, 40.$)$ Slide No. 2022.

Photos 5-7. Osmunda Claytoniana. Three stages in the division of the protoxylem and origin of the pinna trace to a fairly large secondary pinna. ( $x$ I 40. ) Slide No. 1978.

Photo 8. Todea barbara. Preparation for origin of the trace to the seventh lowest pinna on a fertile branch of the leaf. The separating groove of parenchyma reaches to the undivided protoxylem. ( $x$ I 40.) Slide No. 1994.

Photo 9. Todea hymenophylloides. More advanced stage of a similar origin of a pinna trace. The xylem of the branch-trace is about to separate. ( $x$ 1 40.) Slide No. 2025.

Photos IO, II. Osmunda regalis, var. pahustris, horticultural variety congesta. The origin of the traces to the top free pinnae of two branches. In Photo Io the protoxylem has become definitely mesarch and is dividing. In Photo I I the branch-trace has passed off, but the inner protoxylem remains mesarch. ( $X$ I 40. ) Slide No. 1948.

'It corresponds, I believe, with a line passing through the "marges' of C. E. Bertrand. 
Photos 12 and 13. Todea barbara. Origin of trace to the ninth lowest pinna (sterile) on a fertile branch of a leaf. The protoxylem does not divide, but passes off with the branch-trace. ( $x$ 140.) Slide No. 1996.

Photo 14. Todea superba. Origin of trace to the pinna of a branch of a leaf; the adaxial metaxylem is reduced to a single trachea. ( $x$ I 40.) Slide No. 2015.

Photos 15 and 16 . Todea hymenophylloides. Origin of trace to twenty-second main pinna from top of a leaf; some of the soft tissues lining the concavity of the xylem of the main trace accompany the protoxylem when preparing to divide. ( $x$ I 40.) Slide No. 2024 .

Photos 17 and 18 . Todea superba. Origin of trace to the second smallest top branch of a leaf. Similar to Photos 15 and 16 , but the bay filled with soft tissues is more marked. ( $x$ 67.) Slide No. 2012.

Photo 19. Osmunda bipinnata. Origin of trace to the third undivided pinna at the top of a leaf. There is a bay of soft tissues, but the adaxial xylem is reduced to two tracheae. ( $X$ I 40.) Slide No. I97. 


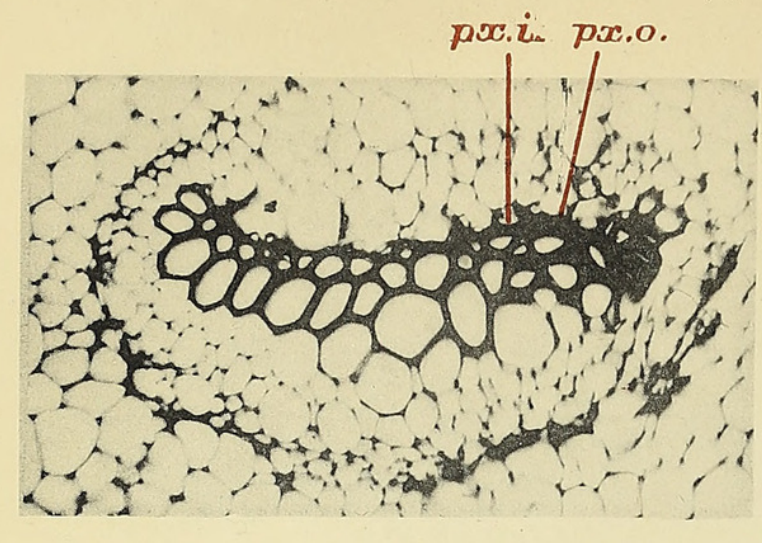

1.

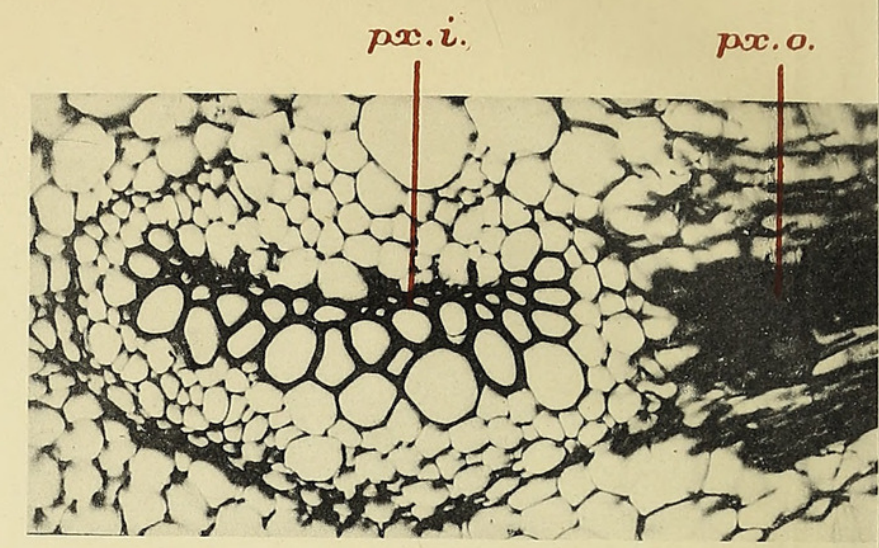

2 .

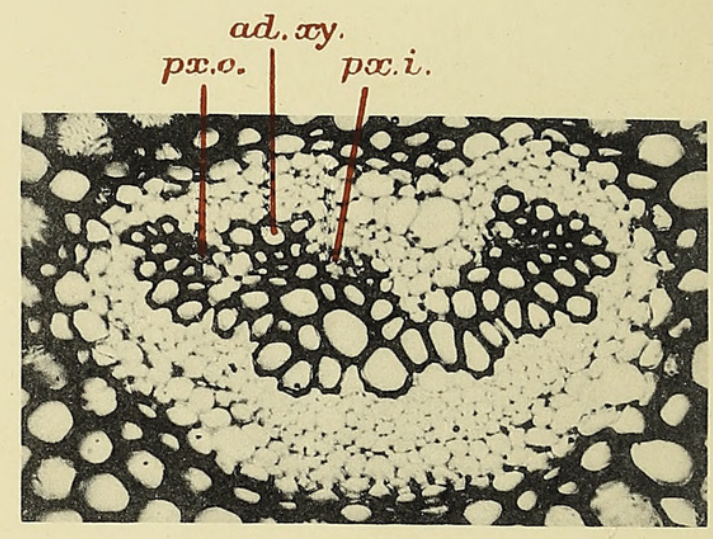

4.

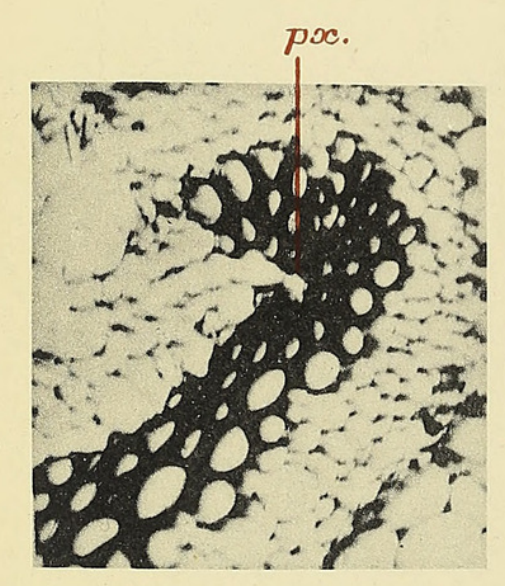

5 .

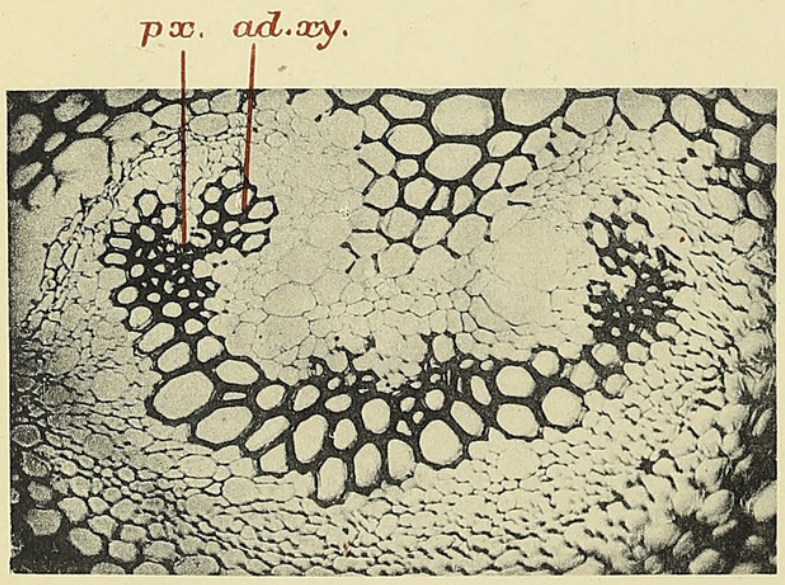

8

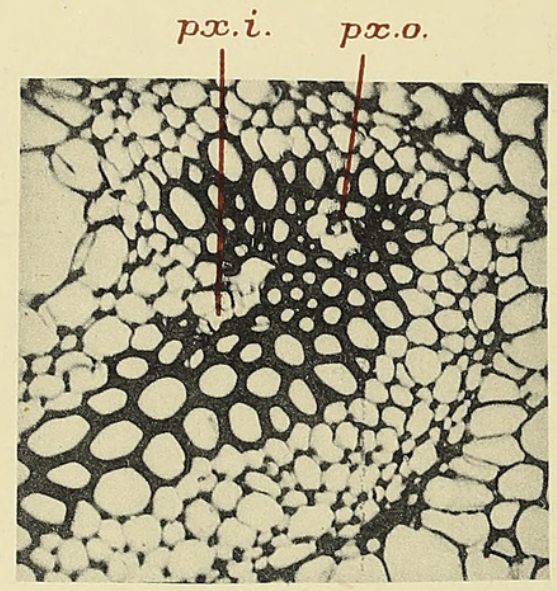

6.

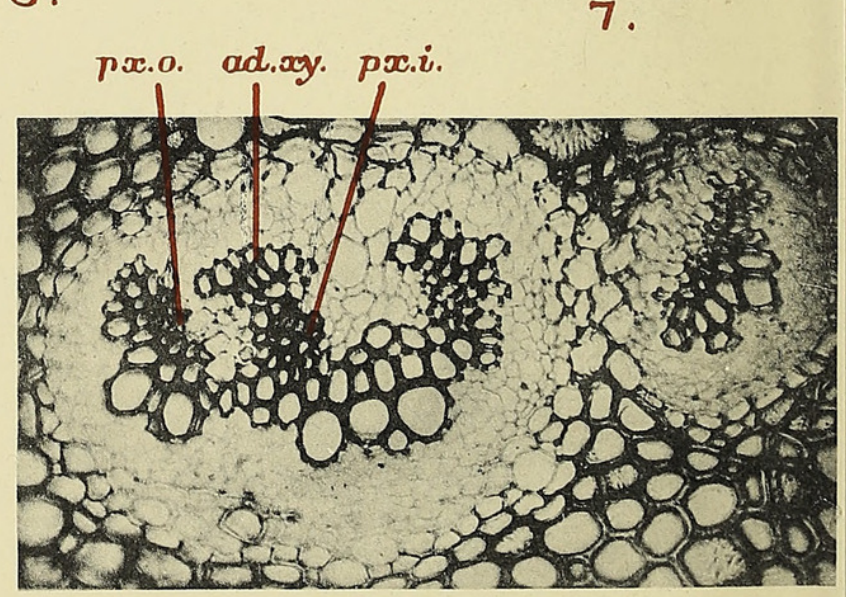

9. 


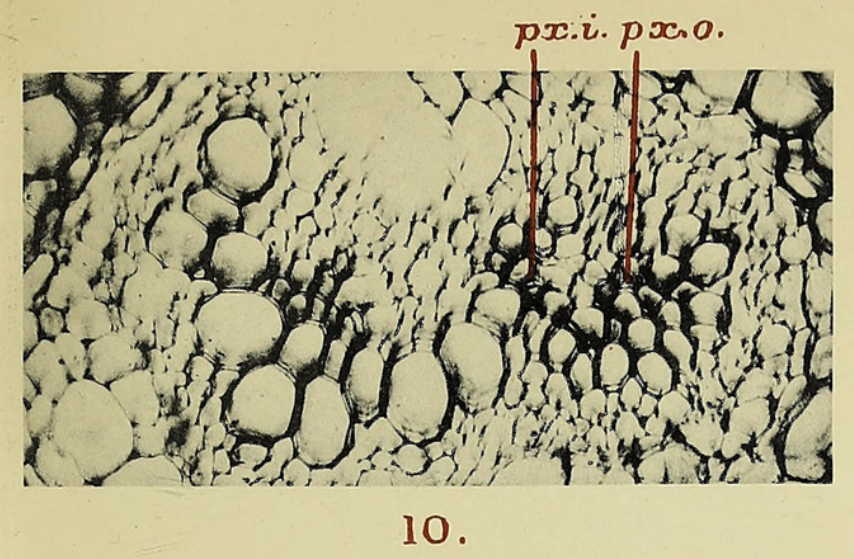

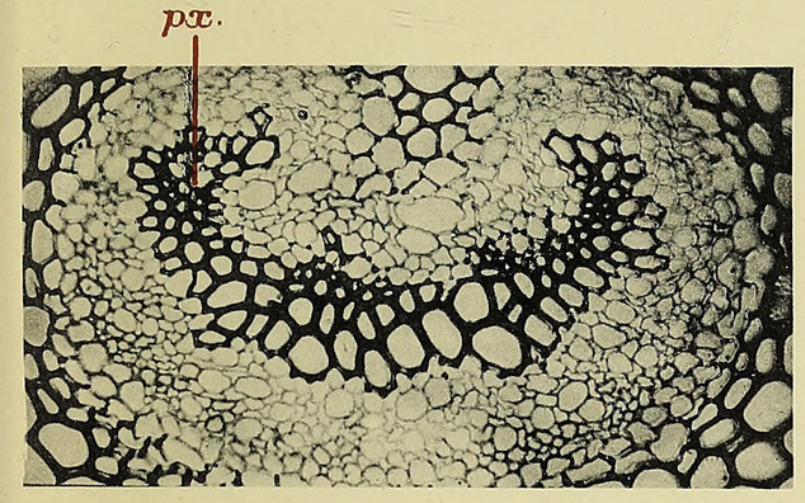

12.

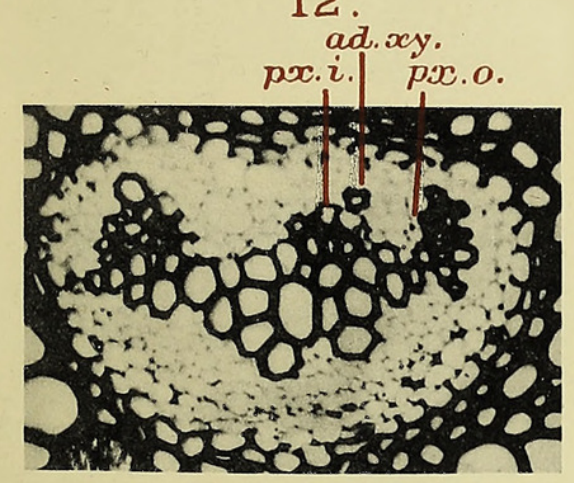

14.

px.i. ad. $x y$. px.o.

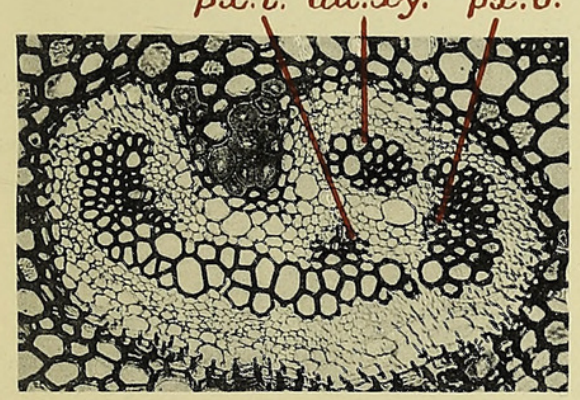

17.

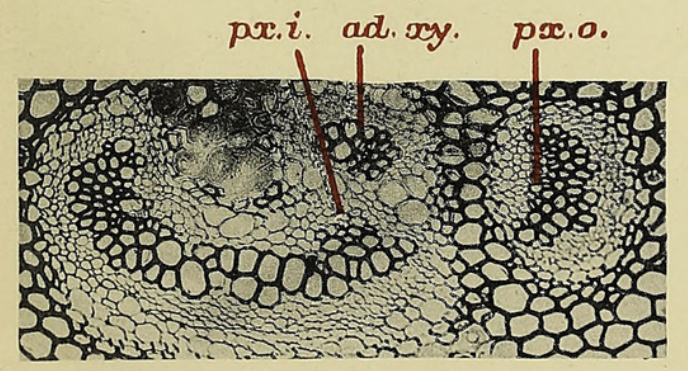

18.

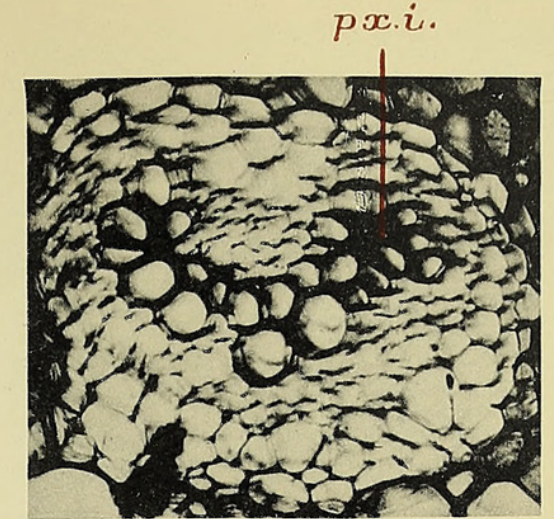

11.

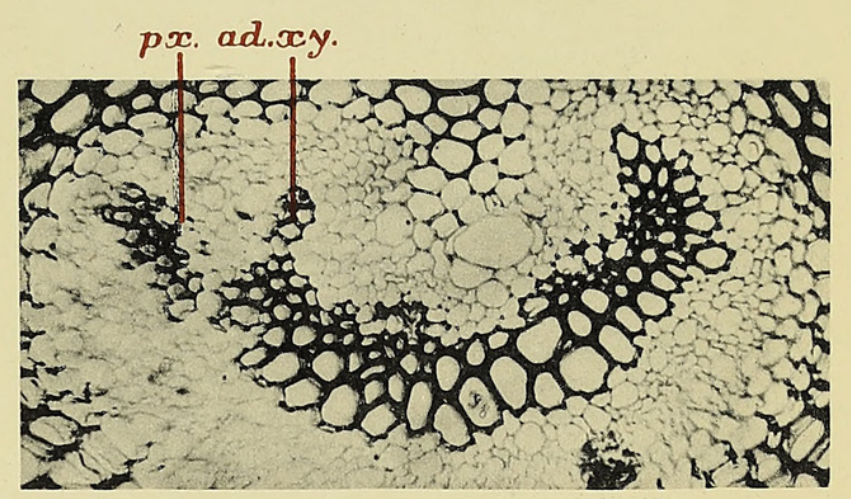

13.

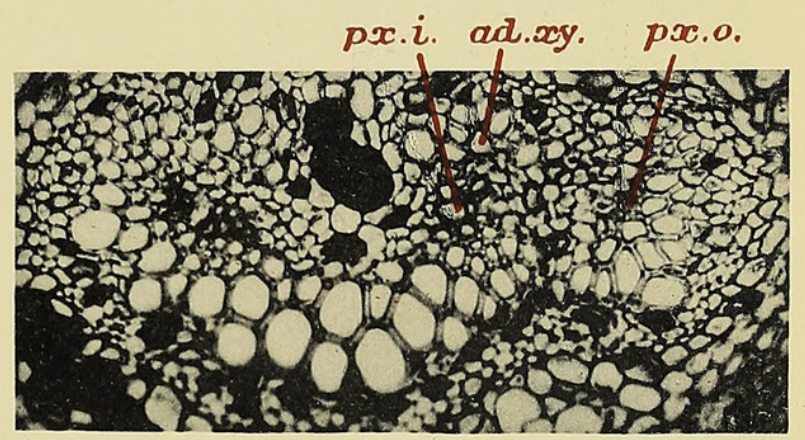

16.

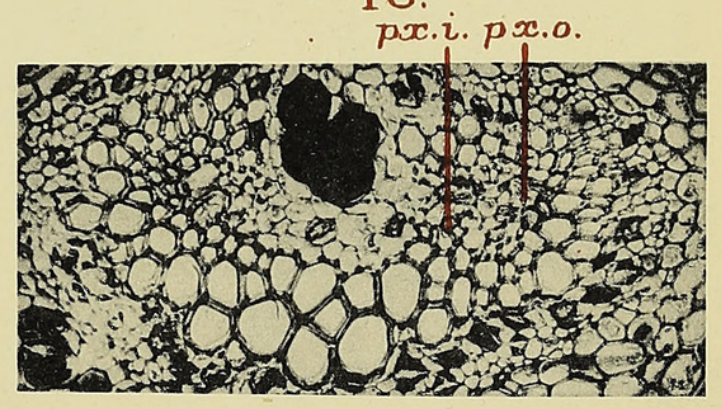

15.

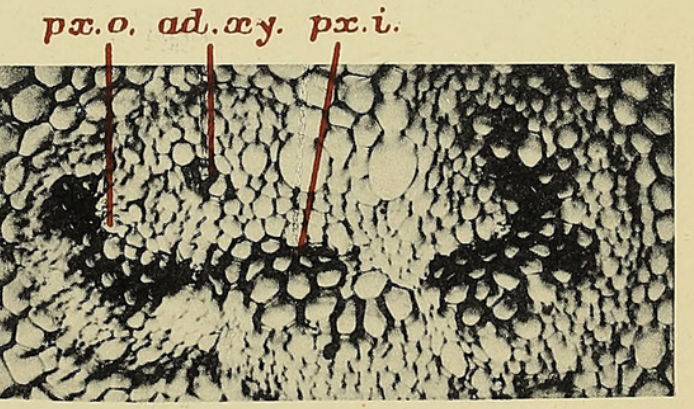

19. 


\section{$2 \mathrm{BHL}$ Biodiversity Heritage Library}

Gwynne-Vaughan, D. T. 1916. "Observations on the anatomy of the leaf in the Osmundaceae." Annals of botany 30, 487-493.

https://doi.org/10.1093/oxfordjournals.aob.a089619.

View This Item Online: https://www.biodiversitylibrary.org/item/237452

DOI: https://doi.org/10.1093/oxfordjournals.aob.a089619

Permalink: https://www.biodiversitylibrary.org/partpdf/320136

\section{Holding Institution}

Smithsonian Libraries

\section{Sponsored by}

Biodiversity Heritage Library

\section{Copyright \& Reuse}

Copyright Status: Not in copyright. The BHL knows of no copyright restrictions on this item.

This document was created from content at the Biodiversity Heritage Library, the world's largest open access digital library for biodiversity literature and archives. Visit BHL at https://www.biodiversitylibrary.org. 